\title{
Policy and Prediction: The Case of Institutional Diversity in Romanian Higher Education
}

LAZĂR VLĂSCEANU ${ }^{* 1}$ AND MARIAN-GABRIEL HÂNCEAN ${ }^{2}$

$\approx$ Presenting key elements of post-1990 historical developments in the Romanian higher education system, the emphasis is put on recent (2011) policies of increasing higher education institutional differentiation. The view is that, in policy design, due attention should be paid to both historical roots and predicted developments. Building on an institutional analysis approach, we put forward a theoretical model that aims to explore the predictive implications of some recently promoted higher education policies. These policies are expected to increase institutional differentiation at the systemic level and enhance quality in teaching and research at university level. The predictive capacity of a model of reference is tested against a concurrent model. The key assumption of the latter is that of considering higher education institutions (HEIs) as "cooperative systems" that are unable to generate those outputs and outcomes that, by aggregation, would contribute to the construction of an institutionally diverse and heterogeneous higher education landscape.

Keywords: institutional differentiation, macro-level systemic incentives, policy and prediction, Romanian higher education

$1 \quad{ }^{\star}$ Corresponding author. Department of sociology, Bucharest University, Bucharest, Romania lazarvlasceanu@gmail.com

2 Department of sociology, Bucharest University, Bucharest, Romania 


\section{Politike in predvidevanje: primer institucionalne raznolikosti romunskega visokega šolstva}

LAZĂR VLĂSCEANU* IN MARIAN- GABRIEL HÂNCEAN

× Predstavljeni so ključni elementi zgodovinskega razvoja romunskega visokošolskega sistema po letu 1990, poudarek pa je na najnovejših politikah (2011), ki težijo k povečanju institucionalne raznolikosti v visokem šolstvu. Pogled, ki je predstavljen, kaže, da je pri oblikovanju politik treba pozornost posvetiti zgodovinskemu ozadju in tudi predvidenemu razvoju. S pomočjo metode analize institucij je predstavljen teoretični model, s katerim avtorja poskušata raziskati napovedane posledice nekaterih pred kratkim promoviranih politik visokega šolstva. Za te politike se pričakuje, da bodo prispevale $\mathrm{k}$ povečanju institucionalnega razlikovanja na ravni sistema pa tudi povečanju kakovosti poučevanja in raziskovanja na univerzitetni ravni. Napovedana zmogljivost referenčnega modela je testirana ob vzporednem modelu. Ključna predpostavka zadnjega je upoštevanje visokošolskih ustanov kot »kooperativnih sistemov«, ki ne zmorejo ustvariti takih učinkov in rezultatov, ki bi - ob združitvi - prispevali k izgradnji institucionalno raznolike in raznovrstne krajine visokošolskega izobraževanja.

Ključne besede: institucionalna raznolikost, spodbude sistemskih sprememb na makroravni, politike in predvidevanje, visoko šolstvo $\mathrm{v}$ Romuniji 


\section{Introduction}

In the context of massification, higher education institutions (HEIs) are under pressure to meet the various requirements and needs of their direct and indirect beneficiaries (Reichert, 2009). Higher education systems with diverse and differentiated institutions are considered to have an increased capacity to satisfy the various expectations of beneficiaries. This essentially means that systems with greater institutional diversity may be regarded as a desirable outcome (van Vught, 2008). Several dimensions of such an outcome are usually considered: provision of wider and diverse learning opportunities, increased capacity for institutional adaptation to students' needs, and increased institutional flexibility in responding to domestic and wider social changes.

Institutional differentiation and institutional diversity bear different meanings. Differentiation is commonly seen as a dynamic process in a higher education system whereby either the existing HEIs follow specific trajectories of development, making them as distinct as possible from others, or new entities have a better chance of emerging in the system. Differentiation is thus a process benefitting from those incentives induced in the system that make each HEI assert its distinction. Institutional diversity is the end result of differentiation. It indicates the variety of entities already existing or the ways in which new entities may emerge and become consolidated within a system. Diversity may take various forms: systemic diversity, structural diversity, programmatic diversity, procedural diversity or reputational diversity (van Vught, 2008).

A key problem in the age of massification concerns ways of achieving increasing institutional diversity when a set of systemic incentives for increased institutional differentiation have been induced. We address this problem below with reference to recent policy initiatives and their developments in the Romanian higher education system.

\section{The Romanian higher education system since 1990}

During the last 23 years, the Romanian higher education system has moved from a "state controlled model" through a "state supervisory model" towards a "beneficiary-oriented model" (Păunescu, Florian, \& Hâncean, 2012; Taylor \& Miroiu, 2002). Developments in each new stage have been dependent on those from the previous stage; that is, developments have been "path dependent". In order to substantiate such a stand, let us look more closely at the recent history of Romanian higher education and provide some relevant data and information. 


\section{Transformations and stages in post-199o higher education}

During the communist regime, the dominant pattern of development was that of a state controlled model (i.e., the higher education system was dominated by high degrees of centrality and top-down policy approaches). Between 1990 and 2010, the institutional model changed into a "state supervisory model" (i.e., HEIs were allocated extended degrees of freedom and autonomy, while the state retained its regulatory and supervisory powers). During this period, the top-down approach to designing and providing public policies continued to be a feature of the system. Irrespective of the sources of institutional changes - domestic or European - the state retained its central position in deciding the main directions to be followed. In this context, the primary tool for the state to influence developments in higher education remained associated with the public funding stream as it was, with strong quality evaluation instruments and policies. New changing initiatives have started to take shape since 2008, firstly by undertaking a thorough analysis of the higher education system and institutions, and then by submitting a "strategy of modernisation" together with its normative legal basis. This "strategy of modernisation" has initiated a new stage in the development and transformation of the Romanian higher education system, properly supporting a new institutional framework: a beneficiary-oriented approach. The way of designing and implementing public policies within higher education has been radically changed. As a salient effect, there has been a change from a top-down approach (with the state having the central role and functions) to a bottom-up approach (with HEIs having a strong say and role in their institutional profiles and missions). One key option of the "strategy of modernisation" has been that of increasing the institutional differentiation of the higher education system, to the level of functionally generating wider institutional diversity.

\section{Data and information on higher education flows}

The number of organisations providing higher education services increased from 48 public universities in 1990 to 108 public and private HEIs in 2010. Moreover, the number of students enrolled in 2008/2009 was five times that of 1990/1991. This is a clear sign that the system shifted from elite education, at the end of the 1980s, to intensive massification, starting with the beginning of the 1990s. However, the total number of enrolled students has been decreasing since 2009, mostly because of a sharp demographic decline. Furthermore, the number of doctoral students has decreased since 2005/2006. 
Teaching staff has not increased in correlation with the increase in the total number of enrolled students. Taking as a reference the ten-year period from $2001 / 2002$ to $2009 / 2010$, the student/teaching staff ratio generally increased from 22:1 in 2001/2002 to 30:1 in 2009/2010. Obviously, the quality of teaching and, indirectly, the time for research have decreased.

The massification of Romanian higher education has not been correlated with an adequate increase in critical resources (e.g., teaching staff stock, financial inputs, etc.). Moreover, there has not been a uniform massification process. Some fields have been exposed to a massive increase in student numbers (e.g., social sciences and humanities), while others (e.g., sciences and engineering) have faced a steady decrease in students. These different threads have produced some contradictory effects. On the one hand, as already mentioned, a huge increase in the student/staff ratio has taken place, while, on the other hand, faculties whose study programmes have benefited from massification have tried to enrol as many students as possible as a means of improving their funding streams. Meanwhile, faculties whose study programmes have been confronted with decreasing rates of student enrolment have focused on research as a means of securing academic standards and additional financial resources. However, on the whole, an unintentional consequence of such developments has dramatically emerged: the higher education system has become highly inefficient. The ratio of graduates to enrolled students has decreased (e.g., in 1990/1991 there were 25,927 graduates for 192,810 enrolled students, while in 2005/2006 there were 112,244 graduates for 716,464 enrolled students). In other words, the cost of delivering one graduate has consistently increased since 1990.

Another emerging trend concerns the expansion of distance learning. For instance, in 1999/2000, only $2 \%$ of the student population was enrolled in distance learning programmes, while in 2006/2007 we witness an increase to 23\% (Păunescu, Miroiu, \& Vlăsceanu, 2011; Vlăsceanu, 2010; Vlăsceanu, Miroiu, Păunescu, \&Hâncean, 2011). According to research results, during the period 2004-2008, 6 of the 90 Romanian universities managed to attract 51\% of competitive public research funding, with just 3 universities managing to attract $32 \%$. Such figures sketch a very unbalanced and clustered picture, with a narrow minority of universities accessing the great majority of the competitive public financial resources allocated by the state to research.

\section{Existing institutional configurations and their pitfalls}

Drawing on the empirical evidence selectively mentioned above, we can detect several institutional configurations. Firstly, Romania reveals a high 
number of HEIs relative to the small number of student enrolments and with regard to the demographic size of the country. Furthermore, the number of study programmes in social sciences and humanities (areas with low market demand) is high, while the number of study programmes in science, engineering and other professional areas is low (despite their having a high market demand). Secondly, there is a decreasing demand for higher education degrees due to the diminishing proportion of young people in the population. At the same time, Romania is experiencing (a) a continuous shrinking of public funds made available to public $\mathrm{HE}$ and research, and (b) a rather low internationally relevant and competitive research output. Thirdly, the system is dominated by a high level of institutional isomorphism in terms of HEIs' assumed missions and with reference to their structures, governance and organisation of curricula. The HE system has revealed reduced institutional differentiation and a growing gap between the stated mission of the HEI and its realisation.

Such configurations in the Romanian system of higher education highlight its lack of sustainability in many respects: systemic inefficiency, high institutional isomorphism, low economic relevance, poor research productivity, decreasing quality provision, etc.

\section{Promoting new policies, particularly in the areas of institutional differentiation}

New policies, legal arrangements ${ }^{3}$ and institutional incentives have recently been put forward to change the system from a state supervisory model towards a beneficiaries-oriented approach. This new institutional approach was inter alia thought to breed higher levels of institutional differentiation and diversity (see Figure 1 and Table 1 ).

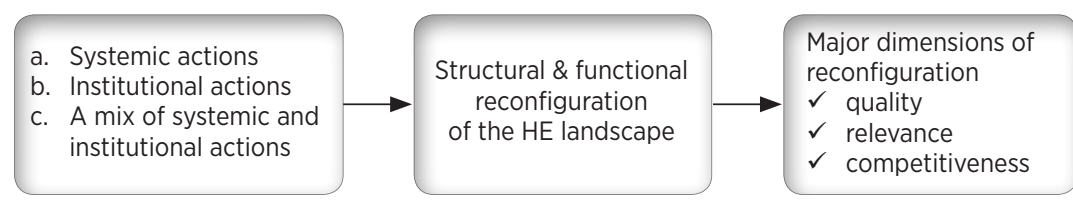

THE CORE OF THE NEW APPROACH: FOCUS ON (DIRECT \& INDIRECT) BENEFICIARIES

Figure 1. Outlining the new institutional arrangements

3 We refer here especially to the Education Act No. 1/2011 and to all its corresponding bylaws (e.g., the methodology for university classification and study programme ranking, the methodology for higher education quality assurance, the methodology for university funding, etc.). 
Table 1. The reconfiguration of the Romanian higher education landscape

\begin{tabular}{|c|c|c|}
\hline a. Systemic actions & b. Institutional actions & $\begin{array}{l}\text { c. A mix of systemic and institutional } \\
\text { actions }\end{array}$ \\
\hline $\begin{array}{l}\text { (i) increasing uni- } \\
\text { versity autonomy } \\
\text { as this is related } \\
\text { to clear means of } \\
\text { accountability; } \\
\text { (ii) producing great- } \\
\text { er institutional } \\
\text { diversity and } \\
\text { differentiation } \\
\text { through univer- } \\
\text { sity classification } \\
\text { and study pro- } \\
\text { gramme ranking; } \\
\text { and } \\
\text { (iii) introducing a } \\
\text { new funding } \\
\text { formula: public } \\
\text { funding depen- } \\
\text { dent on teaching } \\
\text { and research } \\
\text { outputs, and on } \\
\text { real costs. }\end{array}$ & $\begin{array}{l}\checkmark \text { HEls governing } \\
\text { structures: HEls to } \\
\text { opt for either a more } \\
\text { collegiate or a more } \\
\text { managerial type of } \\
\text { governing structure; } \\
\checkmark \text { restructuring institu- } \\
\text { tional missions and } \\
\text { internal organisa- } \\
\text { tion: HEls to set up } \\
\text { their own internal } \\
\text { structures in line } \\
\text { with the prospects } \\
\text { of a new mission } \\
\text { and its successful } \\
\text { realisation; } \\
\checkmark \\
\text { diversifying financial } \\
\text { sources: allowing } \\
\text { universities to set } \\
\text { up commercial } \\
\text { companies and } \\
\text { foundations. }\end{array}$ & 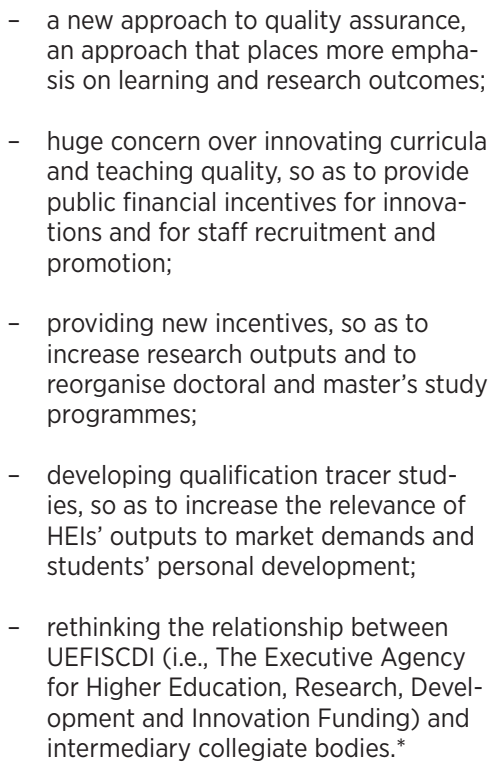 \\
\hline
\end{tabular}

Note:

* Put somewhat differently, this rethinking is to set up and/or strengthen buffer collegiate bodies, under the umbrella of an executive agency (i.e., UEFISCDI) meant to provide national and international information on higher education and to increase inter-institutional communication.

The implementation of the new institutional arrangements began in 2011, after the new Education Act (No. 1/2011) was passed. The process of reconfiguring Romanian higher education is only at an early stage; important outcomes are to be expected both in the near future and in the longer term. Nevertheless, the institutional differentiation process has had a solid start, already producing effects. We refer to the University Evaluation Exercise ${ }^{4}$ (UEE) conducted by several national collegiate councils (i.e., the Romanian Agency for Quality Assurance in Higher Education - ARACIS, the University Research Council - CNCS, the Council on the Attestation of University Qualifications and Degrees - CNATDCU, all in close cooperation with the European University Association - EUA). The aims of the UEE include: (a) university classification: to classify HEIs into three clusters, according to their stated mission and academic outputs; (b) study programme ranking: to rank study programmes in

4 By the UEE, we refer to both University Classification and Study Programme Ranking. 
terms of their academic and research outputs. Study programme ranking has been mainly quantitatively oriented, while university classification has been built on both qualitative and quantitative assessment, in order to identify the extent to which each university manages to accomplish its stated mission and strategic goals. The qualitative evaluation exercise has been carried out by independent European expert teams mobilised by the EUA within its Institutional Evaluation Programme.

The UEE aims at differentiating universities on several axes: research, teaching and learning, relations with the national and international environment, and institutional capacity. It is expected to produce two types of differentiation: (a) classifying universities into three classes (i.e., research intensive, research and teaching, and only teaching-focused universities); and (b) ranking study programmes into five categories (i.e., A, B, C, D and E) across ranking academic domains. University classification produces only nominal differentiated classes, while study programme ranking produces ordinal (hierarchical) categories of study programmes, in terms of quality and outputs.

The outcomes of the UEE are connected to degree-awarding powers and financial incentives. For instance, universities placed in the teaching-focused class would be prevented financially (out of public sources) from the right to organise doctoral studies. At the same time, study programmes ranked as category A are to receive more money, while study programmes ranked as category $\mathrm{E}$ will not receive any public funding. The quantitative component of the UEE was completed in 2011. It involved collecting and processing raw data on the aforementioned criteria. ${ }^{5}$ Such data are made available on an open public website. ${ }^{6}$ The process faced a number of methodological and theoretical constraints, which demanded several academic debates in order to identify: (i) an acceptable range of indicators for measuring institutional outputs; (ii) strategies of populating each indicator with those data that allow for a fair national comparability across institutions; (iii) formulae for relating indicators and identifying university classes; (iv) optimal ways of allocating weighting to each indicator in the overall assessment of institutional outputs. The initial evaluation provided the first classification of universities and the first study programme rankings. ${ }^{7}$ Once the quantitative side of the exercise was accomplished, the

5 The variables corresponding to the evaluation criteria were issued through Ministerial Order No. 4174/2011, available at http://chestionar.uefiscdi.ro/docs/OMECTS\%204174\%2omodificare\%20 OMECTS\%204072.pdf (Romanian only, retrieved on 2 April 2012).

6 See for this issue http://chestionar.uefiscdi.ro/ (Romanian only, retrieved on 2 April 2012).

7 The results of the university evaluation exercise - the quantitative evaluation - are available at http://chestionar.uefiscdi.ro/ (Romanian only, retrieved on 2 April 2012). 
qualitative evaluation of each university was initiated and is currently under way (see Table 2).

Table 2. The main components of the University Evaluation Exercise

\begin{tabular}{|l|l|l|}
\hline 2011 & $\begin{array}{l}\text { Quantitative evaluation component } \\
\text { Statistical analysis of empirical raw } \\
\text { data. }\end{array}$ & $\begin{array}{l}\text { Outputs } \\
\text { Preliminary evaluation of universities }\end{array}$ \\
$\begin{array}{l}\text { 4 evaluation criteria: teaching and } \\
\text { learning, research, relations to envi- } \\
\text { ronment, institutional capacity. }\end{array}$ & $\begin{array}{l}3 \text { categories of universities } \\
\text { (research intensive, research and } \\
\text { teaching, and teaching-focused } \\
\text { universities); } \\
\text { in each ranking domain, a study } \\
\text { programme ranking into 5 classes } \\
\text { (A, B, C, D and E). }\end{array}$ \\
\hline 2012-2015 & $\begin{array}{l}\text { Quantitative evaluation component } \\
\text { Visits of evaluation foreign expert } \\
\text { teams to each university. }\end{array}$ & $\begin{array}{l}\text { Outputs } \\
\text { Final evaluation of universities }\end{array}$ \\
$\begin{array}{l}\text { Qualitative evaluation criteria: to } \\
\text { what extent each university satisfies } \\
\text { its assumed institutional mission and } \\
\text { validation of the outputs produced } \\
\text { by the qualitative evaluation com- } \\
\text { ponent. }\end{array}$ & \\
\hline
\end{tabular}

\section{A way of predicting policy outcomes}

After briefly outlining the historical background and the new policy of institutional differentiation implemented in the Romanian higher education system, a question of further interest is that of predicting outcomes of this policy. In so doing, we take the position that any new higher education policy should be regarded from the perspective of both its historical roots and the predicted consequences of its implementation.

The prediction of policy outcomes may be considered to be of two types: (a) prediction embedded in the policy as such so as to allow for the constant monitoring of policy implementation; (b) prediction made when launching a policy in order to theoretically evaluate its outcomes. The former is empirically grounded and provides a means for achieving optimal policy implementation. It allows for the introduction of corrections during policy implementation and promotes eventual adjustments that compete for better achieving well stated policy objectives. The latter is anticipatory and provides a means for identifying the degree of confidence one may have when opting for implementing a given policy.

For predicting policy outcomes in our case and validating them at this initial stage of policy implementation, we consider two models of interest: (a) 
one predictive model, based on the assumptions of a well known institutional analysis in social sciences (Meyer \& Rowan, 2006), and (b) a concurrent model, aimed at testing the validity of the former.

\section{The predictive model}

The predictive model is a hypothetical model. Building on an institutional analysis approach, the model predicts the behaviour of Romanian HEIs in the context of certain policy incentives. Specifically, the model aims to predict how the beneficiaries-oriented approach is expected to increase institutional differentiation, at a systemic level, and quality in teaching and scientific research, at a university level.

The model builds on the assumption that a powerful external selective incentive system is to steer the behaviour of every HEI. This should occur in spite of intra-university diversity of interests. The model has a three-layered structured pay-off matrix as a building pillar. Firstly, there is the core layer, which highlights several features: (i) increasing differentiation and diversification in order to satisfy students' interests; (ii) increasing university transparency in order to help students make informed decisions; (iii) enhancing the quality of university services and study programme provision according to the institutional assumed mission; (iv) increasing efficiency in public funding and the contribution of Romanian higher education to national socioeconomic development. Secondly, there is the intermediary layer (or incentive schemata), which supports the idea that degree awarding powers and public funding allocation must be based on the UEE results. Thirdly, there is the surface layer, i.e., the rapports between the observed and expected behaviour. On this layer, universities are expected to improve efficiency in their internal use of resources, so as to have as many study programmes as possible within categories A and B (see Table 3). 
Table 3. Expected university structural behaviour

a. Managing university classification

\begin{tabular}{|l|l|l|}
\hline $\begin{array}{l}\text { Research intensive } \\
\text { category }\end{array}$ & $\begin{array}{l}\text { Research and teaching } \\
\text { category }\end{array}$ & $\begin{array}{l}\text { Teaching-focused universities } \\
\text { category }\end{array}$ \\
\hline $\begin{array}{l}\text { University X } \\
\text { University Y }\end{array}$ & $\begin{array}{l}\text { University Q } \\
\text { University P } \\
\text { University Z }\end{array}$ & $\begin{array}{l}\text { University U } \\
\text { University T } \\
\text { University } L \\
\text { University } L(t+1)\end{array}$ \\
$\begin{array}{l}\text { University K } \\
\text { University } L(t+1)\end{array}$ & $\begin{array}{l}\ldots \\
\text { University S }\end{array}$ \\
\hline $\begin{array}{l}\text { Note: Given the incentive schemata, University L might, for instance, try to migrate from } \\
\text { the teaching-focused universities class to the research intensive class. However, if this is } \\
\text { the case, then at the moment t+1 University L should have increased its research outputs, } \\
\text { otherwise this migration will not be possible. Essentially, each university has the possibility } \\
\text { of either migrating to the expected university class or remaining in the corresponding class. }\end{array}$ \\
\hline
\end{tabular}

b. Managing study programme rankings

\begin{tabular}{|c|c|c|c|c|}
\hline \multicolumn{5}{|l|}{ Ranking domain $\alpha$} \\
\hline $\begin{array}{l}\text { Study } \\
\text { programme } \\
\text { class A }\end{array}$ & $\begin{array}{l}\text { Study } \\
\text { programme } \\
\text { class B }\end{array}$ & $\begin{array}{l}\text { Study } \\
\text { programme } \\
\text { class C }\end{array}$ & $\begin{array}{l}\text { Study } \\
\text { programme } \\
\text { class D }\end{array}$ & $\begin{array}{l}\text { Study } \\
\text { programme } \\
\text { class E }\end{array}$ \\
\hline $\begin{array}{l}\text { University } X \\
\text { University } Y \\
\text { University } Z \\
\ldots \\
\text { University } K \\
\text { University } L(t+1)\end{array}$ & $\begin{array}{l}\text { University Q } \\
\text { University P } \\
\text { University R } \\
\text { University W }\end{array}$ & $\begin{array}{l}\text { University } U \\
\text { University } T \\
\text { University } L \\
\text { University } L(t+1) \\
\ldots \\
\text { University S }\end{array}$ & $\begin{array}{l}\text { University J } \\
\text { University I } \\
\text { University V } \\
\text { University M }\end{array}$ & $\begin{array}{l}\text { University N } \\
\text { University I } \\
\text { University G } \\
\text { Un } \\
\text { University H }\end{array}$ \\
\hline \multicolumn{5}{|c|}{$\begin{array}{l}\text { Note: Given the incentive schemata, University } L \text {, for instance, might try to improve the } \\
\text { quality of its corresponding study programme, within ranking domain } \alpha \text {, so as to move from } \\
\text { Class } C \text { to Class } A \text { (at time } t+1 \text { ). If this is not possible, then University } L \text { (at time } t+1 \text { ) might } \\
\text { either seek out alternative funding streams to support the study programme or simply } \\
\text { eliminate the programme from its higher education service package. }\end{array}$} \\
\hline
\end{tabular}

The model predicts that the beneficiaries-oriented approach will generate institutional differentiation and enhance academic quality due to the selective incentives promoted by the policy design. Essentially, for every higher education policy area (e.g., quality assurance, public funding, etc.) that the new institutional arrangements aim to reform or change there is a similar payoff matrix. Secondly, all of the payoff matrices that could be designed have a common core layer (as shown in Figure 2). Thirdly, for the time being, one cannot assess the surface layer, as the implementation of the new institutional arrangement is in a early stage (which is the main reason that it is impossible to empirically test the model at this stage). Still, the theoretical idea of a payoff matrix 
is suitable for application in predicting the outcomes of the UEE policy when considering its advanced implementation. For all of the major changes that the new institutional arrangement is expected to deliver in other areas - such as quality assurance, public funding, etc. - one could envisage similar payoff matrices. Fourthly, we theoretically predict a small variance between expected and observed behaviour for every payoff matrix (in respect to quality assurance, public funding, etc.).

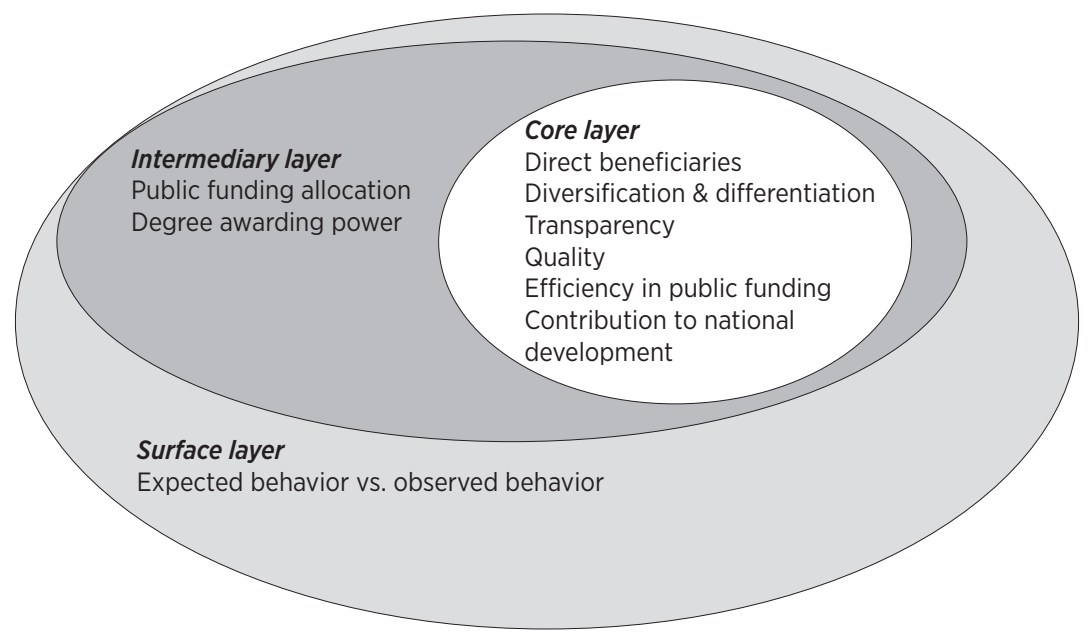

Figure 2. The three-layered matrix composition of the model

According to the predictive model, one could expect significant differences between the predicted and the observed behaviour under some conditions: (a) the incentives are not allocated properly; (b) the content of the core layer is to be significantly modified in the near future; (c) the results of periodical political elections will change the payoff matrix.

\section{The concurrent theoretical model}

To test the validity of the predictive model, a concurrent model, composed of several theoretical elements, may prove useful. Our proposed concurrent model is based on several assumptions, all of them having been already demonstrated elsewhere. 
1. Universities ${ }^{8}$ are cooperative systems, comprising diverse groups of interests that try to fulfil their agendas by informal structuring. These groups contribute to the achievement of the general goals of university as long as university is seen as a means for satisfying their specific interests (Pfeffer, 1995, p. 73). Incidentally, if university members fail in their attempts to satisfy their agenda of interests, their contributions to the organisational processes begin to decrease, putting the achievement of university objectives at risk. As systems of cooperation, universities are considered to include a large diversity of groups: students, administrative apparatus, academics and researchers, top management, representatives of professional associations, employers, etc. (Reichert, 2009). This highly diverse composition generates a high level of diversity of interests, which may sometimes be divergent or antagonistic. In the given context, within universities, informal internal structures might greatly affect and deter the optimal functioning of the formal internal structure (Scott, 2003).

2. HEIs operate as professional bureaucracies. The top management of universities is loosely coupled with the operating core. Incidentally, the behaviour of academics and researchers cannot be properly guided or controlled by formal arrangements. This dual structuring is due to universities operating as professional bureaucracies (Mintzberg, 1993). Within professional bureaucracies, the standardisation of skills is the prime coordinating mechanism, while vertical and horizontal decentralisation is one of the main design parameters. How such arrangements operate has a bearing on envisaged outcomes and on any HE policy implementation.

3. The informal structures of HEIs are preeminent and greatly affect the functioning of formal internal arrangements. The configuration of the internal structures of HEIs impacts organisational efficiency. One should further consider the fact that universities are embedded in a thick and dense fabric of networks of relations and shaped by a diverse array of institutional arrangements, which has strong implications for their level of homogeneity or diversity (DiMaggio \& Powell, 1983).

4. Changing the institutional environment is not sufficient to produce a change in internal organisational cultures. HEIs are assumed to vary in terms of their organisational cultures and specificity. Changing internal informal institutions is difficult without major interventions in internal organisational cultures.

8 In Romania, all of the HEIs accredited by the Romanian Quality Assurance in Higher Education (ARACIS) are labelled as universities; otherwise, they are simply termed as HEIs. However, in spite of this legal distinction, in the present paper we refer to universities and HEIs without discriminating between them. 
The concurrent model argues that the observed behaviour of any HEI is primarily the result of a mix of formal and informal structuring configurations. External stimuli would stand a low probability of generating linear outcomes, mainly when considering the fact the university's diverse interest groups have a filtering impact. Consequently, the same external institutional arrangements might produce different outcomes within the same population of HEIs. In other words, the probability of the same institutional framework producing the same outcomes in a population of HEIs has a sparse distribution.

\section{Confronting the models}

When grasping the concurrent model, universities struggle against internal constraining forces emerging from the great diversity of their constituents. When grasping the predictive model, HEIs must cope with forces emerging from external systemic institutional arrangements. The two models predict different outcomes vis-à-vis the beneficiaries-oriented approach. The point is to theoretically estimate whether institutional differentiation might be reached, providing that the institutional arrangements are adequately implemented.

According to the predictive model, the new systemic institutional arrangements should produce institutional differentiation. The selective incentives are causal mechanisms differently affecting both HEIs and their stakeholders in a coherent manner. Here, we are referring to several aspects: prospective students would make informed decisions, top management of universities would adopt and pursue adequate institutional missions, academics would set their career ladders within a competitive environment, and public funding would primarily follow excellence in teaching and scientific research, and would avoid poor quality study programmes. The model predicts outcomes in a linear manner.

The concurrent model, on the other hand, predicts outcomes in a nonlinear manner. The effects of external formal arrangements are filtered and affected by intra-organisational informal and formal structures. On these grounds, it might appear extremely difficult to support the idea that systemic public policies reach their expected objectives in a coherent manner. Consequently, if this is the case, systemic institutional arrangements should be subject to constant review.

As the HE reform in Romania is currently under way, we are not able to empirically test the two alternative models. However, one could envisage another type of testing. For instance, one could test the two models against each other hypothetically. The results could be used to indicate which model entails the highest probability of making sound predictions. Let us further use 
this approach in order to demonstrate the importance of having a predictive approach embedded in any policy design and implementation.

Within the Romanian higher education landscape, HEIs are highly dependent on their external environment. All of their critical resources (e.g., prospective students, public funding, legitimacy, sources of reputation, etc.) are to be found outside their settings. In order to access the desired critical resources, universities must adapt their behaviour to the requirements of the external environment. Striving for critical resource access and managing external forces, universities of the system, as a specific population of organisations, adopt a process of institutional isomorphism. This institutional isomorphism, delivered through the attempts of organisations to survive and reach optimisation, will feature high levels of homogeneity.

Institutional isomorphism is triggered by three mechanisms: coercive isomorphism, mimetic isomorphism and normative isomorphism (DiMaggio \& Powell, 1983). During times of institutional reforms, universities are generally confronted with powerful coercive isomorphism. This is the case in the Romanian higher education landscape: HEIs must legally meet all formal requirements. As the predictive model shows, all HEIs are compelled to make the necessary adjustments in order to observe the systemic institutional arrangements. These adjustments imply not only organisational mechanisms and operations, but also require academics and other staff and students to undertake corresponding actions within their settings. In other words, the incentives brought forth by the Romanian reforms are so strong and diverse that they involve not only the top management of universities but also their operating cores. Even if HEIs respond in the same manner to the coercive isomorphism imposed by the state authorities responsible for higher education, they are institutionally differentiated using the same criteria.

The concurrent model's prediction, that the internal formal and informal structures of HEIs would filter out the effects produced by systemic public policies, cannot be supported theoretically. However, we might expect some HEIs to slow the process of adopting changes, due to their organisational cultural profiles.

On such theoretical grounds, and despite the lack of empirical testing, we are inclined to admit that the predictive model entails a high probability of correctly predicting the outcomes expected to be produced by systemic reform. Providing that the policy is further implemented and refined without becoming affected by political quarrels, we are confident, at an acceptable level of probability, that the envisaged institutional differentiation will come about and generate its further codes of configuration. 


\section{Conclusion}

The Romanian higher education landscape is currently shifting from a state supervisory model to a beneficiary-oriented approach. The newly provisioned institutional arrangements aim to produce institutional differentiation and to enhance quality in teaching and research.

Building on an institutional analysis approach, we have provided the historical background of the current higher education policy in Romania and have demonstrated the need for a predictive dimension in any higher education policy. With regard to the latter, we have theoretically discussed the possibility of predicting the future behaviours of Romanian HEIs. To this end, two alternative models of prediction have been proposed: the predictive model and the concurrent testing model. The former predicts that the currently emerging institutional arrangements, delivered by the Romanian reform, are expected to increase institutional differentiation at the systemic level and enhance quality in teaching and research at the university level.

The capacity of the predictive model to produce strong predictions is proposed to be tested against a concurrent model of HEIs envisaged as cooperative systems. The concurrent model argues that, at a structural level, HEIs could generate outputs and outcomes that, by aggregation, do not contribute to the construction of an institutionally diverse and heterogeneous higher education landscape. After testing the two models against each other, we theoretically claim that the predictive model would entail a higher probability of better predicting the outcomes expected to be produced by the systemic reforms. The concurrent model may be valid only if systemic institutional arrangements imply organisations adopting changes in a top-down manner. When HEIs are affected by selective incentives, the changes directly permeate at all levels. Under these circumstances, the ability of HEIs to filter out the impact of systemic institutional arrangements is significantly reduced. 


\section{References}

DiMaggio, P. J., \& Powell, W. W. (1983). The Iron Cage Revisited: Institutional Isomorphism and Collective Rationality in Organizational Fields. American Sociological Review, 48(2), 147-16o.

Meyer, H.-D., \& Rowan, B. (2006). The New Institutionalism in Education. Albany: State University of New York Press.

Mintzberg, H. (1993). Structure in Fives. Designing Effective Organizations. New Jersey: Prentice-Hall, Inc.

Păunescu, M., Florian, B., \& Hâncean, M.-G. (2012). Internalizing Quality Assurance in Higher Education: Challenges of Transition in Enhancing the Institutional Responsibility for Quality. In A.

Curaj, P. Scott, L. Vlăsceanu, \& L. Wilson, European Higher Education at the Crossroads (pp. 317-338). Dordrecht Heidelberg New York London: Springer .

Păunescu, M., Miroiu, A., \& Vlăsceanu, L. (2011). Calitatea învățământului superior din România. Iaşi: Polirom.

Pfeffer, J. (1995). Incentives in Organizations: The Importance of Social Relations. In O. E.

Williamson, Organization Theory. From Chester Barnard to the Present and Beyond (pp. 72-97). New York \& Oxford: Oxford University Press.

Reichert, S. (2009). Institutional Diversity in European Higher Education. Brussels: EUA.

Scott, R. W. (2003). Organizations as Rational, Natural and Open Systems. Upper Saddle River, New Jersey: Pearson Education, Inc.

Taylor, J., \& Miroiu, A. (2002). Policy-Making, Strategic Planning, and Management of Higher Education. Bucharest: CEPES.

van Vught, F. A. (2008). Mission Diversity and Reputation in Higher Education. Higher Education Policy, 21(2), 151-174.

Vlăsceanu, L. (2010). Universities and Reflexive Modernity. Budapest \& New York: Central European University Press .

Vlăsceanu, L., Miroiu, A., Păunescu, M., \& Hâncean, M.-G. (2011). Starea calității în învățământul superior. Barometrul Calității 2010. Braşov: Editura Universității Transilvania. 


\section{Biographical note}

LAZĂR VLĂSCEANU is a professor of sociological research methodology at Bucharest University, Department of Sociology. He has been involved in various projects related to higher education policy design and implementation, both in Romania and elsewhere. He published research papers and volumes on social research methodology, sociology of education and culture, and higher education reform and policy making. More recently, his research interests have focused on social and cultural issues of higher education in the age of reflexive modernity (Cf. Universities and Reflexive Modernity. Institutional Ambiguities and Unintended Consequences, CEU Press, 2010).

MARIAN- GABRIEL HÂNCEAN is an associate professor at Bucharest University, Department of Sociology, where he teaches undergraduate and MA level courses in sociology of organizations, organizational behaviour and organizational networks. His main research interest focuses currently on understanding organizational performance from a social network perspective. $\mathrm{He}$ also does research on the organizational behaviour of universities from an institutional analysis approach. In this area, his main research interests concern higher education ranking mechanisms and benchmarking procedures. 